\title{
The safeguard of a rural landscape and of its use. Study on the western-south of Lazio (Italy).
}

\author{
Nora Lombardini ${ }^{11}$ \\ ${ }^{1}$ Politecnico di Milano, School AUIC, Dept. ABC, Italy
}

\begin{abstract}
The paper analyses the policy of the preservation and enhancement (from the economic point of view) of the rural landscape in the western-south of Lazio, and especially in the territory of Agro Pontino. The final act of the reclaimed land, during the Fascism, was realized with the development of the main preservation laws on what, nowadays, is defined as "cultural heritage" but, at that time, was described as "things of historical and artistic interests" and "natural beauties".

The development of the policy of the Italian preservation went in parallel with a deep interesting on the rural world, representing the base of the national economy.

The paper starts from the Italian liberal policy of the first decade of the $20^{\text {th }}$ century, considering the maturing attention on the Italian territory between the needs of the economic emergencies (and the rural settlement planning) and the necessary attention of the land management.

The investigation on the interaction of the economic interests with the cultural (and political) necessity of the safeguard of the national territory must underline the role of public and private interests, and their influence, on the use of the territories and on the realization of the marshes of the Agro Pontino, a new reclaimed geographical area, very close the beautiful land of the ancient Vulcan of Lazio (nowadays "Parco dei Castelli Romani").
\end{abstract}

\section{Introduction}

As the Modscapes programme states

Modscapes aims to explore, document, and raise awareness around this largely underestimated shared cultural heritage, which has seldom been the topic of international and interdisciplinary research. Modscapes introduces the concept of landscapes as a unifying paradigm between tangible (the built environment) and intangible legacies (the related cultural and socio-political contexts) to bridge the gap between research, practice and policies through a trans-disciplinary approach ${ }^{2}$.

\footnotetext{
${ }^{1}$ Corresponding author: nora.lombardini@polimi.it

${ }^{2}$ Modscapes Project. Retrieved from: https://modscapes.eu/about/ [available on August 2018].
} 
According to this project, it is also necessary to evaluate the item of the research as an expression of cultural heritage that is able to communicate and identify a place recognised as a common and shared value. It is necessary to remember that the Italian regulation on Cultural Heritage $(\mathrm{CH})$ concentrates on safeguarding private property rather than on the definition of what is cultural heritage as more commonly understood.

Nowadays, it is necessary, especially in Italy, to start to develop methodologies useful for the involvement of the people in the protection and conservation profession.

The national culture, represented by the Italian "intelligentsia", defined the object of artistic and historic interest while contemporary policy, instead, sustains the involvement of the people in the identification of what it is possible to define as cultural heritage.

Lowenthal states: "It is so customary to think of the historical past in terms of narrative, sequences, dates and chronologies that we are apt to suppose these things attributes of the past itself. But, they are not; we ourselves put them there" [1] \& [2: 19].

\section{The south of Lazio and the Agro Pontino: several questions}

The subject of this research is the South of Lazio, and especially is focused on the case of the "Paludi Pontine - Pontine Marshes" or "Agro Pontino". The significance of this case study is testified by its very long history (by all the "modern and contemporary" from the $18^{\text {th }}$ century - literature dedicated to the reclamation of the area, and by the ancient literature, starting from the poem Odissea, attributed to Homer and Latin Eneide by Virgil) [3, 4, 5]. The main historical collections, such as that of Nicolaj [6], are devoted to rebuilding the history of the place and of the reclamation, in order to promote and validate other reclamation activities, considering and rooting the new projects in the past and in the reasons pursued at those times.

The historical significance of the southern territory of Lazio is important, both for the history itself and for the ideas that this story has produced in every sector of human knowledge, starting from the earliest times. The area in question includes the Agro Romano, the Colli Albani and the "Agro Pontino" as far as the current borders with the Campania region. It is a place that largely coincides with the Ciociaria, a portion of the geography of Lazio where it is possible to recognize a specific identity. Its geographical complexity has influenced its physical and historical reading and interpretation: actually, the three portions that we can make it coincide with the Agro Romano, the Colli Albani and the Agro Pontino (which is part of the homonymous plain) have been seen as separate entities both from a historical and cultural point of view. A further geographical-cultural distinction is made between the Campagna Romana, in the south including the Agro Romano and the Colli Albani, and the Agro Pontino, which extends as far as Terracina and the National Park of Circeo. The overlapping of these different appellations, rather than differentiate the geographical areas, tries to identify different cultural, highlights the problematic nature of interpretation and illustration of this territory.

Vincenzo Monti, an important poet and translator of classic Latin literature, in 1784, on the occasion of the reclamation project of Pope Pius VI (the most important reclamation before the fascist one) wrote a poem referring to the attempts to drain the marshes in the Pontine region (the territory of Pomezia, from which the toponym etymologically derives).

The reclamation was designed and started, several times, by the Romans (at the time of the Republic and the Empire); then by Theodoric, Ostrogoth king of Italy and, 
after, by several Popes, till the solution by Pius VI, whose marks it is possible to find on the territory nowadays, as referred by [7:38].

This territory, since the ancient times, was effect by the impact of the human activities, which is not only in the management of the territory, but also the narration of the territory itself. This immense literature, is not dedicated exclusively to the description of the "historical" events of this portion of Lazio, but constitutes a human interpretation of a complex and difficult landscape. If the Agro Pontino is assumed as the starting point of this review and the reclamation carried out in the Fascist era, the event that brought to completion the reclamation that the historiographical tradition tells us developed, with different techniques since the Volsci occupation, it becomes difficult to understand how the landscape was interpreted in ancient times. In fact, today, it is difficult to accept the idea of a landscape where wild and civil elements mingled in an order with unknown rules [6: 1]. The archaeological evidences attest human settlements that make believe an ancient use of the territory both in residential and agricultural terms.

In the reconstruction of the cultural value of a territory, the sense that this territory has had in the past as well as in the present is also important. This means: to recognize a different story, through time and space; to use the awareness to safeguard this diversity and, in the same time, to guarantee the cultural valorisation and use the territory itself, trigging activities of implementation and valorisation from the economic point of view. In the specific case, obviously, we need to distinguish "profitability" as a cultural asset, then as a "common good", and "profitability" as a reality endowed with its market value, capable of producing income: that is, it is possible to speak of the territorial and urban reality as a common cultural asset and a private good [8].

Returning to the interpretation of the territory and the value that the most remote past may have given to the territory itself, it is possible to say that: "Only the modernist interpretation of ancient agrarian structures has generated, in the current mentality, the idea that all the swampy areas had always been subjected to intense reclamation work, at least during the periods of economic prosperity" [9: 15-16] \& [9: 51]. On the other hand, as Traina emphasizes, the same terminological definition of the marshes, in antiquity, is subordinated to the translation problems related to what is the meaning of the term palus. The palus, even in its plural paludes, assumes a negative sense in front of the "positive" ager, that is the cultivated land, and seems to refer to an ideological importance of the reclamation, as it is explained by [9: 123].

The Republican and Imperial ages of the Roman period provided for hydraulic works, conditioning human settlements with the construction of villas dedicated to rural activities and with the attempt to implement the economy of the place, linked to fishing, agriculture and all the rural activities. In particular, as Lugli points out, in $358 \mathrm{BC}$, the Romans added to the 25 tribes, already existing and recognized, the Pomptina Tribus (Liv VII, 15), a very fertile land whose grain was as appreciated as the that from Cuma and from Sicily. In the same time, the population in Terracina were ascribed to the Oufentina tribe established in $318 \mathrm{BC}$ and whose name derives from the river Ufente that crosses the entire marsh and goes out to the sea near Terracina, called in Roman period colony Anxurnas (from the Volsci's toponym). The new colony, subjected to the law and the government of Rome, was founded in 329 BC with the sending of 300 colonists who received two jugeri of good rural land, as is also testified by archaeological evidence. $[10,11]$. These are projects connected with a strong ideological implication dictated by needs of prestige and by necessities to raise government revenue. The hydraulic works by Pius VI seem to be linked to these aims.

The advent of the Historical Left in power (at the end of the $19^{\text {th }}$ century and the first decade of the $20^{\text {th }}$ century) and, then, even more, during the Giolittian Era, which 
pointed to the fight against the spread of the marshes and malaria, was able to trigger a strong policy for the rehabilitation of the environment and, then, the complete reclamation of the Italian marshes [12]. Fascism took its political chance coming from the Historical Left. For Mussolini, starting from the propagandistic and ideological dimension, there was also the reform to enhance the use of the territory from the agricultural point of view and the need to interrupt the unproductive institute of the latifundium [13]. The need to reform the economy was one of the priorities during Fascism, not only for the government, but also for scholars. Arrigo Serpieri, in fact, lent his knowledge and his reform to activate the process of reclamation of the Pontino, a process that acquires mainly, if not exclusively, an economic-political value, but in which the attention to the landscape was not contemplated.

The geographical, geomorphological, climatic and hydrographic analysis, as well as the description of fauna, flora and vegetation attested to the purpose of describing the present situation, highlighting however, the environmental conditions and their interesting interconnection with the nomadism of the people with farm animals (here present only seasonally to occupy the housing structures formed by the hut and the fence for pets, and so-called lestre).

Today the conditions of the Agro Pontino, as a zoological environment, is completely changed, [...] but this will be a field of study extremely useful for the biologist. It is not easy, in fact, to have a region that changes all of a sudden in all its characteristics: [...] it will be very interesting from the scientific view to keep behind all the changes that will take place in the flora and fauna $[14,15]$.

Political propaganda interests prevailed. For this propaganda the history of previous reclamation, (whether with a positive result or a negative outcome) underlined the necessity of the work and it was useful to demonstrate the organizational and scientific capacity of the government in agrarian property reform, that is seen as a driving force of economic development, particularly in the moment of autarky.

The land transformation in the Pontine countryside did not have the desired results: the real involvement of private property did not materialize, despite the advantages promoted by the Serpieri law on the Integral Reclamation. The Opera Nazionale Combattenti, the main institution in charge of developing the agrarian reform, in 1936, in order to guarantee the subsistence families to the settlers, was forced to introduce a guaranteed minimum income.

Mangullo [16: 8] states that the Second World War overwhelmed and destroyed what had just been built in the Agro Pontino, and that "the complete agrarian transformation, the stabilization of the land and the farm population, remained, however, goals not yet reached". After the war, the situation under Christian Democratic governments was as follows, as also stated by Mangullo [16: 22]: "about 8 thousand hectares of land surface were submerged, while 4 thousand were devastated by fighting". $83 \%$ of pre-war livestock was lost. Less than $35 \%$ of the farms suffered "minor" damage; between 35 and $80 \%$ had suffered "serious damage"; over $80 \%$ of the farms were "destroyed."

The history of the Agro Pontino in the period of reconstruction, and subsequently, is linked to the Cassa del Mezzogiorno, a special public institution in charge of supporting the development of the South-Middle Italy, which started work in the late Fifties. The Cassa assumed "the task of reconstructing and completing the reclamation: it restored and strengthened the hydraulic works, completed the agrarian transformation and financed the realization of all those services and infrastructures that did not yet exist or were insufficient..." as is quoted, again, by Mangullo [16: 22]. 
Although not homogeneously along the Agro, the investments for the upgrading of agricultural activities and infrastructure (including electrification, aqueducts, "social viability" and "productive viability") in the decade 1950-1960 were really important. The strengthening of the infrastructure and the viability of connections with Rome and Naples were more intense in the second five years, as a prelude to the industrialization process that would follow [16: 51] \& [7].

What has been said up to now refers to important changes in a landscape that has always had an agricultural vocation - the same vocation attested by Roman historians as in recent times. However, the modern perception that the population, including the public administrations, have and have had of this territory, in recent times, is not clear.

The cities have grown because the land was sold cheaply while, in 1951, the InaCasa, a governmental plan, was launched. The foundation cities in the Agro Pontino began to expand. Pennacchi writes that the population of Latina from 1960 to 1964 rose, with housing units increasing from 50,000 to 57,000 : where the Farmer's House had been a twenty-two-floors skyscraper was erected (see [18: 406]).

Very briefly, the action of the Cassa per il Mezzogiorno is based on three guidelines: the completion of reclamation, the large-scale irrigation, and the investment for land transformation. The consistency of these public investments, also attracted middle and upper middle-class investors who bought land to build villas and holiday homes (see [16: 100] and [19: 71]). The Cassa del Mezzogiorno not only supported agriculture but was also the most important state-owned financing body in the industry. In the decade 1951-1961 there was a doubling of companies carrying out construction, manufacturing and other activities as noted in [16: 83 (table 8)].

In 1958, a nuclear power plant was built by ENI, an Institution supported by the Government in Borgo Sabotino (Latina). The plant came into operation in 1963 and then stopped work after the 1987 referendum. Since 2000 a dismantling plan has been implemented by the Sogin Society. The plant is still visible today and is the subject of guided tours [20].

The abolition of the Cassa per il Mezzogiorno in the 1980s and the progressive dismantling of the power station marked the beginning of a new historical phase. It must be stressed, very briefly, that the Pontine territory is not the subject of particular protection policies, partly because they support a culture that, at least in Italy, does not show particular attention to the landscape and, especially, is not able to find a connection between the aesthetic and rural dimension of the territory. Specifically, no attempt is made to link agricultural and industrial production with the safeguarding of the naturalistic aspects [21].

Through the regional law 14/1999 the Province of Latina has formulated the project "Monitoring of Water" paying attention to the state of the water in the territory of its competence, as provided for by Legislative Decree 152/1999 and EEC Directive $2000 / 60 / E C$. This is a renewed interest that is rooted in the knowledge of the territory; in the linkage of good management practices (including the participation of stakeholders) with the real territorial needs and in the recognition of the constructive value of biodiversity.

The study of the territory opens, on one hand, to the concept of the bioregion [22]; on the other to the need to assess the impact that agricultural and industrial production has on the territory, activating processes of protection and enhancement of rural heritage. Among the various aspects of the problem, it is impossible to ignore the connections between agriculture and immigration. In short, the ethnical landscape, which involves the introduction of new crops that trigger the development of new competitive fruit and vegetable markets, makes use of favourable infrastructure, such 
as the road and rail systems and the presence of the Fondi city market, one of the most important in Italy and in Europe [23, 24].

\section{The protection of the cultural values of the Agro Pontino}

The studies that the Modscapes project is conducting on the Agro Pontino reflect the desire to enhance the cultural value of this territory. Therefore, it seems necessary to define this cultural value. In particular, today, where is it possible to find such values? The answer is simple: in what the Agro Pontino is today, in its articulated historical and aesthetic dimensions, both in its most interesting realities and in its "beautiful" and "bad" manifestations.

How can the cultural value of the Agro Pontino be managed? Through a series of activities that facilitate awareness of the value of the territory. It is a cultural value and an economic value. The policies, today, must protect the "agricultural landscape" and must recognize and connect the historical, artistic and architectural values of the built and archaeological heritage. During the design and construction of the Agro Pontino reclamation, natural beauties were governed by the landscape law $n^{\circ} 204 / 1922$ while the management of things of historic and artistic interest is ensured by the law $n^{\circ} 364 / 1909$. What happens to the landscape and archaeological heritage during the reclamation? Today we would add: what happened to the rural and peasant traditions of the area, including agricultural products and rural infrastructures?

Certainly, the question of agrarian landscape is more recent and emphasizes the history of the productivity of place and the ways of exploiting them. For this reason, the construction of the events of the Agro Pontino could start from its name ager, through the "negative" association of palus (with which it was referred in modern times, from the $16^{\text {th }}$ century to the reclamation) until the recovery of epithet agro, to underline the success of the Fascist reclamation and to indicate its agricultural potential or, in any case, productive (therefore, also, industrial) meaning.

We must not forget the decisive interdependence that natural landscape and productive landscape (with all its infrastructure) assumes in the concept of agrarian landscape or rural landscape, with the addition of the historical and archaeological value by which the site is distinguished. Despite the law of 1909, the operations carried out for the reclamation, starting from the law for the complete reclamation, did not consider the archaeological value of the heritage. Certainly, the official publications, including the reports published in 1935 by the Institute of Roman Studies, a cultural regime organ founded in 1925, do not refer to the historical value of the territory, focusing, "only", on the history of land reclamation, although from the earliest times.

It was Giuseppe Lugli, an important authority on Roman archaeology, who promoted the knowledge of the archaeology of Agro with two volumes, the first two in the editorial project titled Forma Italiae or Carta Archeologica d'Italia. Entitled, both, Ager Pomptinus, the first is dedicated to the archaeological heritage of Anxur (the current Terracina), the second to the Circei, that is the archaeology of Mount Circeo. The volumes were published, the first, in 1926 and, the second, in 1928 as a result of surveys, certainly carried out a few years earlier the start of projects and remediation works [25]. Although the publications don't seem to be explicitly connected to the land reclamation, Lugli anticipated the publication of the lands of the Regio Prima Augustea (Lazio and Campania) even if the Etruscan archaeological map for Tuscany was already arranged $[10,26]$. The survey is geo-locating the findings in the two analysed areas on the maps of the Military Geographic Institute. 
Four studies were published in different times in the Forma Italiae Collection, and it is interesting to note that they were dedicated to the archaeology of the Agro at different very important moments for the history and the exploitation of this land [26, 27, 28]. While the first and the second, by Lugli, fall at the time of the Fascist reclamation, the third, edited by Piccarreta, in the 1970s, affects the period in which the negative and speculative reflections on the post-war reconstruction were maturing in Italian culture, even under the influence of journalistic investigations by Antonio Cederna [29, 30]. Journalistic investigations and men of culture (the Italian cultural elite), like Pier Paolo Pasolini [31], highlighted the lack of attention to the use not only of the territory but also of the implementation tools that regulated its use. These are the same years in which the Ministry for Cultural Heritage was established in Italy (1974/75).

The survey by Piccarreta underlines how the reclamation, first, and the industrial structures, later, contributed to the loss of the physical traces of the history of the territory, as it is exemplified in [27: 8-9 (Figs. 1-2)]. The Agro Pontino is not, at that time, neither bound nor protected. The ancient via Appia, which crosses this territory, joining Rome to Naples and then to Bari, as Antonio Cederna recognised, as did the most recent journey-chronicle by Paolo Rumiz [32], has been lost in several sections, partly due to the Fascist reclamation.

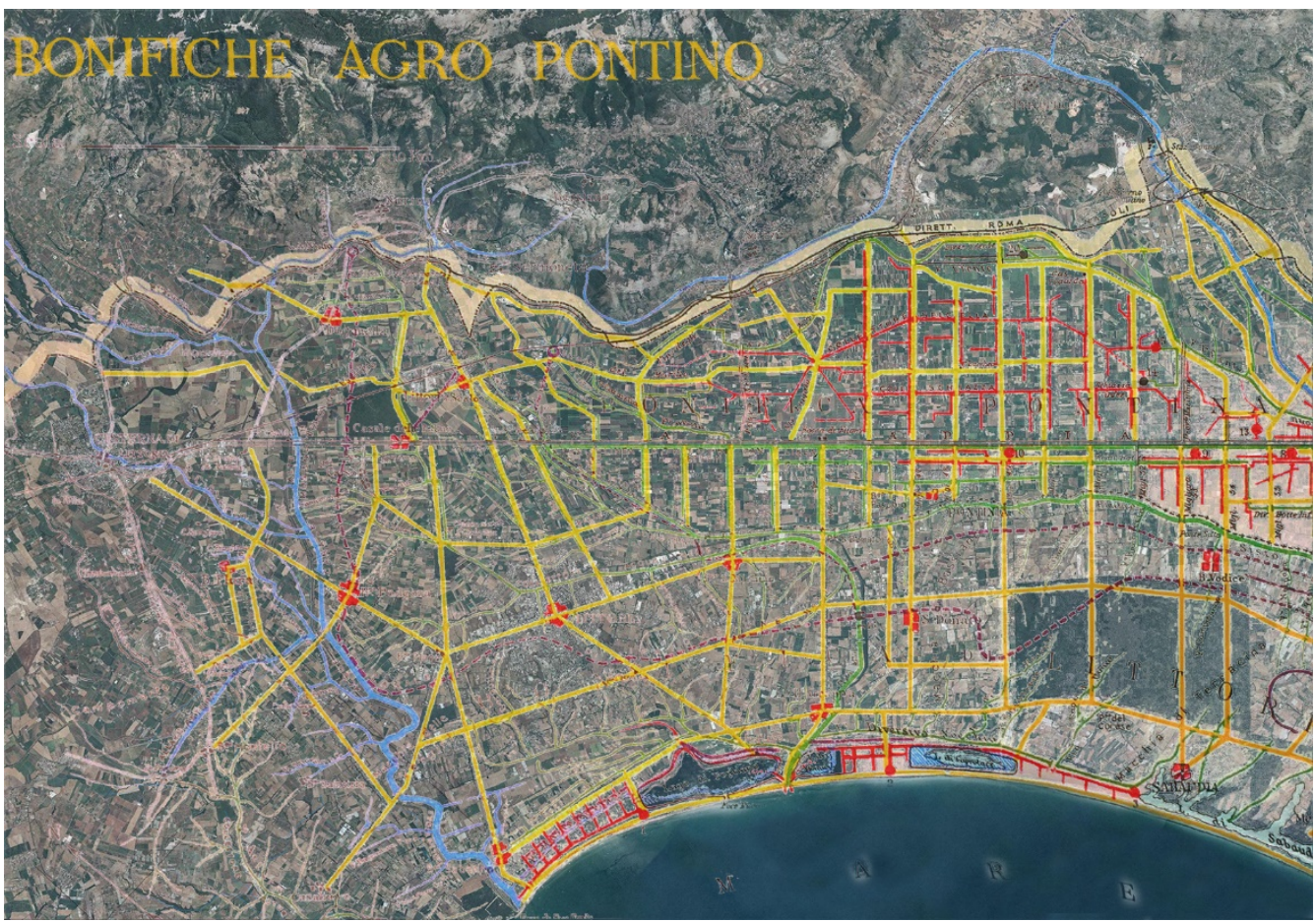

Figure 1. The overlay of the map of the reclamation of the Pontine Marshes during Fascism on the map of the current urban situation. The simple comparison shows the important changes due to the different and new use of the territory. (Source: elaboration by N. Lombardini and $\mathrm{E}$. Fioretto on the basis of [37] and Map of the situation up $2006^{3}$ ).

Parpagliolo, one of the most important jurists lent to $\mathrm{CH}$ in the period under examination, in a work published by the Istituto di Studi Romani and dedicated to the

${ }^{3}$ Ortofoto, Ispra, Progetto IFFI.

Retrieved from: http://193.206.192.136/cartanetiffi/carto3.asp?cat=11\&lang=IT\# 
urban planning of the Castelli Romani, the hinterland between Agro Pontino and Rome, laments the weakness of the protection law created in 1922, that was unable, in his opinion, to reconcile the public and private interests. Referring to the construction of the Via Appia Nuova, he criticizes the failure to apply the Piani Paesistici, an urban planning tool designed by Gustavo Giovannoni precisely as a guarantee of the areas of respect and protection of the "natural beauties" [33].

The archaeological writing by Lugli follows by two years the establishment of the Circeo National Park, the third in Italy, after "Abruzzo" (1921-22), and the "Gran Paradiso" (1922). In the Fascist period the management of these last two national parks underwent a radical change, passing into the hands of the Forestry Militia. This institution was incapable of developing a good policy to ensure the protection of natural beauty against all forms of risks in the territories of the Circeo which were largely in private hands [34].

In his Preface to Corrado Alvaro's Terra Nuova, Sessa writes: "The reclamation of the Agro Pontino appears to the primitive peoples of the place, the 'eternal shepherds', like a wave that 'falls' on the hut". The doubt as to whether it is progress or rather breaking a secular balance, arises from the first pages of the text: "I wonder if they will leave us here" the old inhabitants of these lands were asking [35, 36].

\section{Acknowledgements}

MODSCAPES is a collaborative research project funded under the HERA - Humanities in the European Research Area 3rd Joint Research Programme dedicated to "Uses of the Past" (20162019). This project has received funding from the European Union's Horizon 2020 research and innovation programme under grant agreement $n^{\circ} 649307$

\section{Short resume}

Nora Lombardini, associate professor of conservation of architectural and cultural heritage, involved in the studies of the valorisation of archaeological area with special attention to the archaeological site in Nemi, in Colli Albani, close Agro Pontino.

\section{References}

1. LOWENTHAL, D. 1985. The Past is a Foreign Country, Cambridge, Cambridge University Press.

2. HARVEY, D. C. 2008. "The History of Heritage", in B. Graham; P. Howard (eds.), The Ashgate Research Companion, to Heritage and Identity, England and USA, Ashgate: 19-36.

DOI: https://doi.org/10036/47576

3. OMERO ( $9^{\text {th }}$ century BC) 1963. Odissea, (transl. by R. Calzecchi Onesti), Turin, Einaudi, book $X$.

4. VIRGILIO MARONE (29-19 BC) 1978. Eneide, (transl. by L. Canali), Milan, Oscar Mondadori, book VIII.

5. Entry "Circe". Treccani on-line. Retrieved from: http://www.treccani.it/enciclopedia/circe/ [available on August 2018]. 
6. NICOLAJ, N. M. 1800. De' bonificamenti delle Terre Pontine, Libri IV: opera storica, critica, legale, economica, idrostatica, Rome, Stamperia Pagliarini.

7. MONTI, V. (1832) 1833. La Feroniade, Lugano, Libreria Italiana e Straniera.

8. TIROLE, J. (2016) 2017. Economia del bene comune, Milan, Mondadori.

9. TRAINA G. 1988. Paludi e bonifiche del mondo antico. Saggio di archeologia geografica, Roma, «L'Erma» di Bretschneider.

10. LUGLI, G. 1926. "Ager Pomptinus - pars prima Anxur-Terracina", Forma Italiae, Regio prima, Latium et Campania, Rome, Unione Accademica Nazionale, Danesi.

11. TITO LIVIO (27-14 BC) 1842. (Ab Urbe Condita) Le Deche di T. Livio, (transl. by P. F. Pizzorno), Savona, Luigi Sambolino, vol. 2.

12. BIAGIANTI, I. 1987. "La legislazione sulle bonifiche nell'Italia unita", Rivista di Storia dell'Agricoltura, vol. 27, $\mathrm{n}^{\circ}$ 2: 235-254. Retrieved from: http://rsa.storiaagricoltura.it/scheda.asp?|DF=3\&IDS=14\&IDP=1 [available on August 2018].

13. CARALLO, S. 2016. Paesaggi di bonifica. Tra memoria storica e progetto, Asita. Retrieved from: http://atti.asita.it/ASITA2016/Pdf/158.pdf [available on July 2018].

14. LEPRI, G. 1935. "La fauna pontina prima e dopo la bonifica", in La bonifica delle paludi pontine, Istituto di Studi Romani, Rome, Casa Editrice Leonardo da Vinci: 93-102.

15. CORTESI, F. 1935. "La vegetazione e la flora della regione pontina", in Op. cit. [14]: 103-120.

16. MANGULLO, S. 2015. Dal Fascio allo Scudo Crociato. Cassa per il mezzogiorno, politica e lotte sociali nell'Agro Pontino (1944-1961), Milan, Franco Angeli.

17. VALLECCHI, U. 1938. "II problema delle comunicazioni nella sistemazione urbanistica dei Castelli Romani", in La sistemazione urbanistica dei Castelli Romani, Rome, Istituto di Studi Romani.

18. PENNACCHI, A. 2015. Canale Mussolini: parte seconda, Milan, Oscar Mondadori.

19. LEONE, D. 2016. "Ruropolis, geografia delle migrazioni in Agro Pontino (Ruropolis, geography of migrations in Agro Pontino)", QU3 - I Quaderni di U3, n 11: 67-76. Retrieved from: http://www.urbanisticatre.uniroma3.it/dipsu/wpcontent/uploads/2017/01/u3_quaderni_11_leone1.pdf [available on July 2018].

20. "Dalla Palude all'Atomo" (2011). Latina Oggi, $1^{\text {st }}$ June. Retrieved from: http://www.borgosabotino.it/site/index.php?option=com_content\&view=article\&id= 793:allinizio-era-un-vanto\&catid=51:centrale-nucleare\&ltemid=108 [available on August 2018].

21. DE LUCIA, V. 1992. Se questa è una città, (preface by A. Cederna), Rome, Editori Riuniti.

22. BUDONI, A., MARTONE, M., ZERUNIAN, S. (eds.) 2018. La Bioregione Pontina: esperienze, problemi, linee di ricerca per scenari di futuro, (Ricerche e studi Territorialisti: 2), Rome, SdT edizioni. Retrieved from: http://www.societadeiterritorialisti.it/wp-content/uploads/2016/01/Ricerche-eStudi-Territorialisti_Vol.-2_La-Bioregione-Pontina-mod.pdf [available on Septembre 2018].

23. OMENETTO, S. 2018. "Il paesaggio agricolo alla luce del fenomeno migratorio nel Lazio. Nuove trasformazioni culturali", in S. Carallo, G. De Pasquale (eds.), AgriCulture. Tutela e valorizzazione del patrimonio rurale nel Lazio, Rome, 
RomaTrePress:

209-219.

Retrieved

from:

http://romatrepress.uniroma3.it/ojs/index.php/agriculture [available on August 2018].

24. CATALDO, S., COPIZ, R., LORITO, A. et al., (eds.), 2014. REWETLAND. widearea programme for improving the quality of surface water in the Agro Pontino by means of natural purification techniques, (Le Scienze: 18), Latina, Edizioni Belvedere, Latina. Retrieved from: http://www.rewetland.eu/life/life/news/140612_Rewetland-final-publication.pdf [available from September 2018].

25. La bonifica e la trasformazione fondiaria dell'Agro Pontino, Opera Nazionale per i Combattenti (1936). Roma, Stabilimento A. Staderini.

26. LUGLI, G. 1928. "Ager Pomptinus - pars secunda: Circei”, Forma Italiae, Regio prima, Latium et Campania, Rome, Unione Accademica Nazionale, Danesi.

27. PICCARRETA, F. 1978. "Astura”, Forma Italiae, Regio I - Volumen XIII, Unione Accademica Nazionale, Istituto di Topografia Antica dell'Università di Roma, CNR, Firenze, Leo S. Olschki Editore.

28. EBANISTA, L. 2017. "Ager Pomtinus I", Forma Italiae, Unione Accademia Nazionale, Sapienza Università di Roma, Unione Accademia Internazionale, Edizioni Quasar.

29. CEDERNA, A. (1956) 2006. I vandali in casa, Rome-Bari, Laterza.

30. CEDERNA, A. 1975. La distruzione della natura in Italia, Turin, Einaudi.

31. BRUNATTO P. 1974. Pasolini e... la forma della città, « lo e... », Rai TV. Retrieved from: https://www.youtube.com/watch?v=btJ-EoJxwr4 [available on 23 May 2018].

32. RUMIZ, P. (2016) 2017. Appia, Milan, Feltrinelli.

33. PARPAGLIOLO, L. 1938. "La tutela delle bellezze naturali dei Castelli Romani nel quadro della dottrina urbanistica", in La sistemazione urbanistica dei Castelli Romani, Rome, Istituto di Studi Romani: 67-79.

34. PICCIONI, L. 1999. II volto amato della patria. Il primo movimento per la protezione della natura in Italia. 1880-1934, (L'uomo e l'ambiente: 34), Camerino, Università degli Studi.

35. SESSA, F. (1935) 1989. "Preface", in Terra Nuova Prima Cronaca dell'Agro Pontino, Milan, Claudio Lombardi Editore.

36. CARLI, S. 2013. "Dalle paludi all'hi-tech, il miracolo Agro Pontino", La Repubblica, 20 September. Retrieved from: https://www.repubblica.it/economia/affari-efinanza/2013/09/30/news/dalle_paludi_allhi-tech_il_miracolo_agro_pontino67555414/ [available on September 2018].

37. PRAMPOLINI, N. 1935. "La bonifica idraulica delle Paludi Pontine", in La bonifica delle paludi pontine, Istituto di Studi Romani, Rome, Casa Editrice Leonardo da Vinci: 141-158.

38. BRANDUINI, P. 2017. "Restauro di una marcita nel parco del Ticino. Quando gli architetti imparano dagli agricoltori”, 'ANANKE, $\mathrm{n}^{\circ} 82$ : 121-132. 